\title{
Overcoming Dormancy of Mayapple Rhizome Segments with Low Temperature Exposure
}

\author{
Muhammad Maqbool and Kent E. Cushman ${ }^{1}$ \\ North Mississippi Research \& Extension Center, Mississippi State University, \\ P.O. Box 1690, Verona, MS 38879
}

\author{
Rita M. Moraes \\ National Center for the Development of Natural Products, School of Pharmacy, \\ University of Mississippi, University, MS 38677 \\ Patrick D. Gerard \\ Experimental Statistics Unit, Mississippi State University, P.O. Box 9653, \\ Mississippi State, MS 39762
}

Additional index words. American mayapple, Podophyllum peltatum, Indian mayapple,

Podophyllum emodi, podophyllotoxin, propagule, chilling, medicinal herbs, alternative crops

\begin{abstract}
American mayapple (Podophyllum peltatum L.) is a rhizomatous, herbaceous perennial found in wooded areas of eastern North America and is a source of the pharmaceutical compound podophyllotoxin. This research was conducted to determine the optimum duration of low temperature exposure in overcoming dormancy of fall-harvested rhizome segments for subsequent use as propagules in greenhouse plantings. Two types of rhizome segments were harvested from the wild and used in this study: two-node rhizome segments consisting of a terminal node and its adjacent one-year-old node and one-node rhizome segments consisting of a single node, other than a terminal node, of unknown age or rhizome position. For growth cycle I, rhizome segments were exposed to low temperature $\left(\approx 4{ }^{\circ} \mathrm{C}\right)$ for $30,45,60,75$, or 90 days, planted in pots, and grown in a greenhouse set at $21^{\circ} \mathrm{C}$. Shoot emergence, shoots per pot, and plant height were recorded. Leaves were removed from plants when senescence first became evident, and leaf area was recorded. For growth cycle II, rhizome segments remained undisturbed in the original pots and were exposed to low temperatures $\left(\approx 4^{\circ} \mathrm{C}\right)$ for 90 days. Pots were again placed in the greenhouse and shoot emergence, shoots per pot, plant height, and leaf area were recorded. Increasing duration of low temperature exposure of rhizome segments up to 75 days appeared to increase percent emergence and plant height and decrease days to emergence, though changes in greenhouse conditions over the study period may have also influenced shoot emergence and plant growth. Two-node rhizome segments exhibited higher percent shoot emergence, shoot longevity, leaf area, and plant height than single-node segments during each growth cycle. Two-node rhizome segments also exhibited fewer days to emergence during growth cycle $I$. Rhizome segments produced no more than a single shoot in growth cycle I, whereas more than one shoot was produced in growth cycle II. Most of the effects of low temperature exposure during growth cycle I persisted throughout growth cycle II. These results indicate that dormancy of mayapple rhizomes can be overcome with low temperature exposure and shoots can be induced to grow at any time of year.
\end{abstract}

American mayapple (Podophyllum peltatum L.) is a rhizomatous, herbaceous perennial found in wooded areas of eastern North America. The plant is a source of podophyllotoxin, a compound used in the manufacture

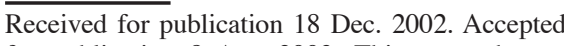
for publication 8 Apr. 2003. This research was supported by NRI Competitive Grant Program 71.2, Award \#2002-01525, and Specific Cooperative Agreement No. 58-6408-7-012. Approved for publication as Journal Article No. J 10253 of the Mississippi Agricultural \& Forestry Experiment Station, Mississippi State Univ. Mention of a trade mark, proprietary product, or vendor does not constitute a guarantee or warranty of the product by Mississippi State Univ. and does not imply its approval to the exclusion of other products or vendors that also may be suitable.

${ }^{1}$ To whom reprint requests should be addressed. E-mail address: kcushman@ra.msstate.edu. of drugs for treatment of cancer, rheumatoid arthritis, genital warts, psoriasis, and multiple sclerosis (Bedir et al., 2002; Beutner, 1996; Lerndal and Svensson, 2000). Because of its podophyllotoxin content, American mayapple is a candidate for domestication and use as a specialty crop in North America. Domestication of American mayapple has the potential of reducing overexploitation of the current source of podophyllotoxin, the Indian mayapple $(P$. emodi Wall), which is an endangered species (Foster, 1993; Rai et al., 2000).

Sexual reproduction in American mayapple is difficult and inefficient (Nautiyal, 1996). Flowers are self-incompatible and do not produce nectar to attract pollinators (Krochmal et al., 1974; Laverty and Plowright, 1988). Fruit set is poor, seeds have a long and persistent dormancy, and seedlings have poor survival rates in the wild (Krochmal et al., 1974; Rust and Roth, 1981). In addition, plants grown from seed remain juvenile for 4 to 5 years before initiating rhizomes (Foerste, 1884; Holm, 1899). Asexual propagation, using rhizome segments, may be the most practical method of rapid propagation.

In the wild, mature plants with well-developed rhizome systems produce shoots in early spring from buds located at the apex of each rhizome. Shoots produce one or two leaves, depending on their sexual status, and then senesce by late spring or early summer. A bud, located on the node from which the shoot arose, elongates horizontally and forms a new rhizome segment. The new segment continues to elongate throughout summer, and the apex becomes a fully developed terminal bud by fall (Foerste, 1884; Holm, 1899). For the purpose of this report, the location of the terminal bud was designated as the terminal node, Nt (Fig. 1A). During the development of this new rhizome segment, the node from which $\mathrm{Nt}$ arises ceases to be a terminal node itself and becomes a 1year-old node, designated as N1. In this way, and over a period of several years, a rhizome system can have many nodes, with each node being sequentially one year older as they become more distant from the rhizome apex. A 2-year-old node, located two nodes distal to Nt, is therefore designated as N2, and so on. (For our purpose, $\mathrm{Nt}$ is the reference point used to describe distal and proximal position.) Ntexerts strong apical dominance over older nodes, and it is the only node to produce a shoot each year. After shoot senescence, Nt can produce more than one new rhizome segment at a time, adding complexity (branching) to the architecture of a single rhizome system. In addition, each node is a complicated structure composed of a highly compressed stem with a terminal bud and many minor buds that remain dormant unless induced to develop into shoots or branches by injury or environment. Roots develop predominantly from rhizome tissue at the base of each node (Foerste, 1884; Holm, 1899).

Dormancy in American mayapple appears to be the result of two influences. First, nodes distal to Nt are dormant as a result of apical dominance. Second, all nodes during fall and winter are dormant. It has been reported that older nodes are released from apical dominance and produce shoots when injury to the rhizome system causes separation from Nt (de Kroon et al., 1991). Dormant rhizome segments harvested in fall, winter, or early spring have been used effectively as propagules in field plantings (Maqbool et al., 2002).

Other plants with a longer history of horticultural manipulation than mayapple also exhibit similar processes of growth, rhizome elongation, and dormancy, and these species may serve as models for mayapple production. Myoga (Zingiber mioga Roscoe) is a herbaceous plant that produces thickened and fleshy rhizomes. Rhizome segments exposed to low temperatures produced twice the number of shoots as those not exposed (Follett, 1991). In another study, uniformity of emergence of myoga shoots was improved by exposure to $4{ }^{\circ} \mathrm{C}$ for 2 to 4 weeks and rate of emergence was hastened by increasing the 

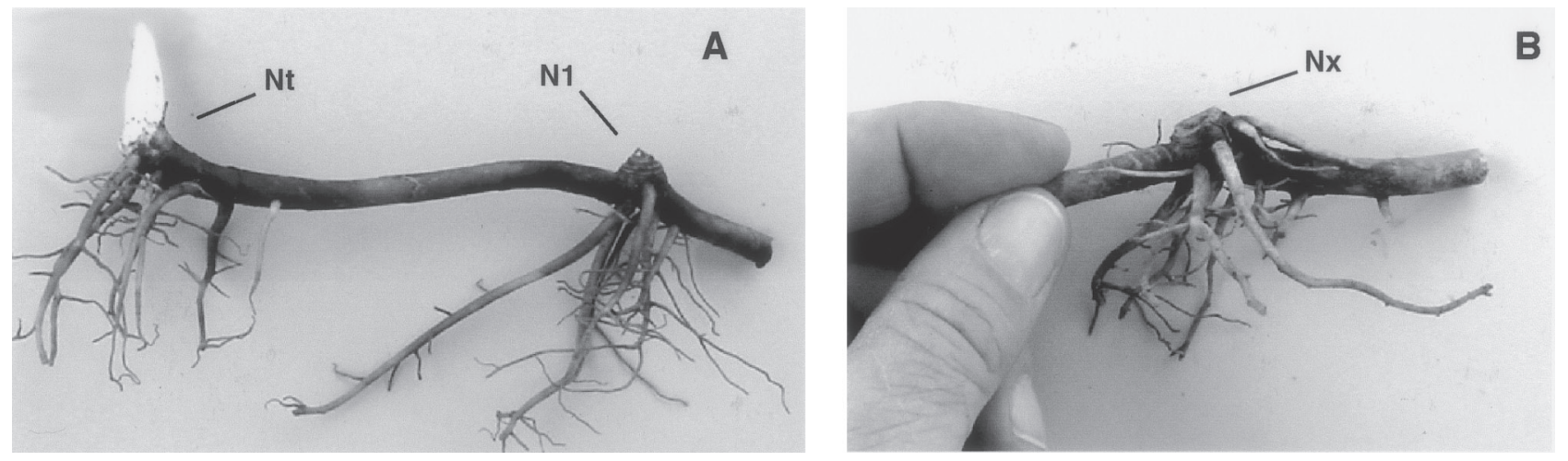

Fig. 1. (A) Two-node rhizome segment of American mayapple, designated as Nt+N1, consisting of a terminal node (Nt) and adjacent 1-year-old node (N1).

(B) One-node rhizome segment consisting of a single node of unknown age or rhizome position, designated as Nx.

duration of low temperature exposure (Gracie et al., 2000). Similarly, low temperature exposures increased sprout emergence and mean number of shoots per propagule of Paeonia L. cultivars and emergence rate was hastened by increasing the duration of low temperature exposure (Fulton et al., 2001). Lily-of-the-valley (Convallaria majalis L.) is another rhizomatous, herbaceous plant that, like mayapple, is often found in wooded areas, emerges in early spring, senesces by early summer, and acquires dormancy during summer and fall. To break dormancy of lily-of-the-valley dormant rhizomes require 1 week at $1{ }^{\circ} \mathrm{C}$ or 3 weeks at $5^{\circ} \mathrm{C}$ (Wareing and Phillips, 1981).

The objective of this research was to investigate duration of low temperature exposure in overcoming dormancy of fall-harvested rhizome segments for subsequent use as propagules in greenhouse plantings.

\section{Materials and Methods}

Mayapple rhizome segments were harvested from one location in the wild, encompassing an area of $\approx 900 \mathrm{~m}^{2}$, near Oxford, Miss., on 4 Dec. 2000. Two types of rhizome segments were used. Two-node rhizome segments consisted of a terminal node and its adjacent 1 -yearold node and were designated as Nt+N1 (Fig. 1A). One-node rhizome segments consisted of a single node, other than $\mathrm{Nt}$, and were of varying ages and rhizome positions from $\mathrm{N} 1$ to about N5. These one-node rhizome segments were designated as Nx (Fig. 1B). Rhizome segments were harvested with roots intact and 4 to $6 \mathrm{~cm}$ of subtending rhizome tissue attached to each node. Rhizome segments were rinsed and treated with $1.32 \mathrm{~mL} \cdot \mathrm{L}^{-1}$ copper hydroxide fungicide (Kocide DF, Griffin, Valdosta, Ga.) for $30 \mathrm{~min}$ to prevent fungal growth during cold storage. Rhizome segments were spread on paper towels overnight to remove excess moisture, placed in plastic bags, and then placed in a dark controlled-temperature chamber at 4 $\pm 2{ }^{\circ} \mathrm{C}$ measured with a temperature recording datalogger (model WD-35710-00, Oakton Instrument, Vernon, Ill.). Rhizome segments were removed from cold storage after 30, 45, 60,75 , or $90 \mathrm{~d}$.

Growth cycle I. After low temperature treatment, rhizome segments were placed in pots ( 15 $\mathrm{cm}$ in diameter and $11 \mathrm{~cm}$ deep; volume $1.5 \mathrm{~L}$ ), one per pot, and placed in a greenhouse under natural light conditions. Average daylength was $10.1,11.0,12.0,13.0,14.0$, and $14.4 \mathrm{~h}$ for months Jan. to June 2001, respectively. The greenhouse temperature was set at 21 ${ }^{\circ} \mathrm{C}$ with two stages of heating and four stages of cooling separated by $1.5^{\circ} \mathrm{C}$ increments. A commercial potting mix consisting of shredded peat moss and vermiculite was used (Jiffy Mix Plus, Jiffy Products, Batavia, Ill.). Fifteen pots per replication were arranged in a greenhouse in a split plot design, with rhizome segment as main plot and duration of exposure as subplot. Plants were watered when the surface of the potting media showed dryness. Plants were fertilized with a slow release $14 \mathrm{~N}-6.12 \mathrm{P}-11.62 \mathrm{~K}$ fertilizer (113 g per pot Osmocote 14-14-14, Scotts Co., Marysville, Ohio) soon after emergence, when plants reached a height of 7 to $10 \mathrm{~cm}$. One month after emergence, soluble 20N-8.74P-16.6K fertilizer (Peters 20-20-20 Peatlite Special, Scotts Co.) was applied at the rate of $100 \mathrm{mg} \cdot \mathrm{L}^{-1} \mathrm{~N}$ with each watering during shoot growth. Every $7 \mathrm{~d}$ thereafter, water was applied to remove any build up of excessive salts in the potting media. Shoot emergence, leaf area, and shoot height were recorded. Leaves were removed at the first indication of senescence and measured using a LI-3100 area meter (LI-COR, Lincoln, Nebr.). Final harvest of leaves was 11 June 2001. Pots remained in the greenhouse for an additional 5 weeks to ensure proper development of new rhizome segments and terminal buds. Pots were kept moist during this time as described above.

Growth cycle II. Pots used in growth cycle I were moistened and again placed in a dark controlled-temperature chamber at $4 \pm$ $2{ }^{\circ} \mathrm{C}$ on 18 July 2001, and all pots (rhizome segments), regardless of the initial duration of low temperature, received low temperature exposure for $90 \mathrm{~d}$. Pots were then placed in the greenhouse on 15 Oct. 2001 using the identical experimental design and greenhouse conditions as growth cycle I. Daily maximum and minimum greenhouse temperatures for growth cycle II were $30^{\circ} \mathrm{C}$ and $17^{\circ} \mathrm{C}$, respectively, as recorded with a max/min thermometer (model 5458, Taylor Precision Products, Oak Brook, Ill.). Average daylength was $11.2,10.4,10.1$, 10.1, and $11.0 \mathrm{~h}$ for months Oct. 2001 to Feb. 2002 , respectively. Plants were watered when the surface of the potting media showed dryness, and soluble $20 \mathrm{~N}-8.74 \mathrm{P}-16.6 \mathrm{~K}$ fertilizer (Peters 20-20-20 Peatlite Special, Scotts Co., Marysville, Ohio) was applied at the rate of $100 \mathrm{mg} \cdot \mathrm{L}^{-1} \mathrm{~N}$ at each watering beginning at shoot emergence. Every $7 \mathrm{~d}$, water was applied to remove any build up of excessive salts in the potting media. Shoot emergence, leaf area, plant height, and shoots per pot were recorded. Leaves were harvested as they senesced and were measured using an area meter as described

Table 1. Percent emergence of shoots arising from mayapple rhizome segments harvested from the wild and exposed to low temperatures.

\begin{tabular}{|c|c|c|c|c|c|}
\hline \multicolumn{3}{|c|}{ Growth cycle $\mathrm{I}^{\mathrm{z}}$} & \multicolumn{3}{|c|}{ Growth cycle II } \\
\hline & \multicolumn{2}{|c|}{ Emergence (\%) } & \multirow{3}{*}{$\begin{array}{l}\text { Low temperature } \\
\text { exposure (days) }\end{array}$} & \multicolumn{2}{|c|}{ Emergence (\%) } \\
\hline \multirow{2}{*}{$\begin{array}{l}\text { Low temperature } \\
\text { exposure (days) }\end{array}$} & \multicolumn{2}{|c|}{ Rhizome segment $^{\mathrm{y}}$} & & \multicolumn{2}{|c|}{ Rhizome segment } \\
\hline & $\mathrm{Nt}+\mathrm{N} 1$ & $\mathrm{Nx}$ & & $\mathrm{Nt}+\mathrm{N} 1$ & $\mathrm{Nx}$ \\
\hline$\overline{30}$ & $0 \mathrm{c} \mathrm{A}^{\mathrm{x}}$ & 13 a $\mathrm{A}$ & 90 & 73 a A & 80 a $\mathrm{A}$ \\
\hline 45 & $40 \mathrm{~b} \mathrm{~A}$ & 20 a A & 90 & 93 a A & 67 a A \\
\hline 60 & 100 a A & 27 a B & 90 & 100 a A & 73 a B \\
\hline 75 & 100 a A & 47 a B & 90 & 93 a A & 73 a A \\
\hline 90 & 100 a A & 40 a B & 90 & 87 a A & 60 a A \\
\hline
\end{tabular}

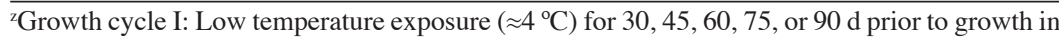
pots in a greenhouse. Growth cycle II: Following senescence, pots were given low temperature exposure $\left(\approx 4{ }^{\circ} \mathrm{C}\right)$ for $90 \mathrm{~d}$ and again placed in a greenhouse. Values are means of 15 replications.

yTwo-node rhizome segment with one terminal and an adjacent 1 -year-old node $(\mathrm{Nt}+\mathrm{N} 1)$. Onenode rhizome segment, not a terminal node, of unknown age or rhizome position $(\mathrm{Nx})$.

${ }^{x}$ Cochran's test used to separate means in columns and rows. Values in columns or rows followed by the same lowercase or uppercase letters, respectively, were not significantly different at $P \leq 0.05$. 
above. Final harvest of leaves was completed on 26 Feb. 2002.

Data other than shoot emergence results were analyzed using the MIXED procedure of SAS (SAS Institute, Cary, N.C.). Random effects for this split-block design were block and block by rhizome segment interaction. Least square means were used to compare combinations of rhizome segment and duration of low temperature exposure in the event of significant interaction. When interactions were not significant, least square means were compared for main effects of rhizome segment and duration of low temperature exposure. Shoot emergence results were treated differently because it consisted of binary response data $(0=$ no emergence and $1=$ emerged $)$ for each subplot unit. Hence, Cochran's test was used to perform multiple comparisons in a pairwise fashion for percent shoot emergence means (Lehmann, 1975).

\section{Results and Discussion}

Growth cycle I. Duration of low temperature exposure and type of rhizome segment affected shoot emergence (Table 1). As duration of low temperature exposure increased from 30 to $60 \mathrm{~d}$, emergence of shoots from $\mathrm{Nt}+\mathrm{N} 1$ rhizome segments increased from $0 \%$ to $100 \%$. Durations $>60 \mathrm{~d}$ also resulted in $100 \%$ emergence, indicating that low temperature exposure of $60 \mathrm{~d}$ or more appeared to be sufficient to overcome dormancy of $\mathrm{Nt}+\mathrm{N} 1$ segments. Emergence of shoots from Nx rhizome segments was not affected by duration of low temperature exposure. These data indicate that low temperature exposure appeared to be more effective in overcoming dormancy of $\mathrm{Nt}+\mathrm{N} 1$ segments compared to $\mathrm{Nx}$ segments. The number of shoots arising from rhizome segments receiving $30 \mathrm{~d}$ of low temperature exposure was not sufficient to measure growth characteristics, such as days to emergence, leaf area, and plant height. Therefore, Tables 2 to 6 do not contain data for $30 \mathrm{~d}$ of exposure during growth cycle I.

There was a significant interaction between duration of low temperature exposure and type of rhizome segment for average $d$ to shoot emergence (Table 2). As duration of low temperature exposure increased from 45 to $75 \mathrm{~d}$, shoots arising from either $\mathrm{Nt}+\mathrm{N} 1$ or $\mathrm{Nx}$ rhizome segments required half as many $\mathrm{d}$ to emerge. Days to emergence for $90 \mathrm{~d}$ of exposure were similar to that of $75 \mathrm{~d}$. When given $90 \mathrm{~d}$ of exposure, however, days to shoot emergence of $\mathrm{Nx}$ rhizome segments increased significantly, to a level equivalent to that of 60 $\mathrm{d}$ of exposure. In a similar manner to that of percent shoot emergence, it can be concluded that durations of low temperature exposure of 60 to $75 \mathrm{~d}$ appeared to be most effective in overcoming dormancy of mayapple rhizome segments.

There was a significant interaction between duration of low temperature exposure and type of rhizome segment for shoot longevity (Table 3). As duration of low temperature exposure increased from 45 to $75 \mathrm{~d}$, longevity of shoots arising from $\mathrm{Nt}+\mathrm{N} 1$ rhizome segments
Table 2. Days to emergence of shoots arising from mayapple rhizome segments harvested from the wild and exposed to low temperatures.

\begin{tabular}{|c|c|c|c|c|c|}
\hline \multicolumn{3}{|c|}{ 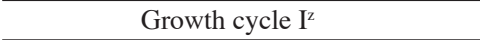 } & \multicolumn{3}{|c|}{ Growth cycle II } \\
\hline \multirow{3}{*}{$\begin{array}{l}\text { Low temperature } \\
\text { exposure (days) }\end{array}$} & \multicolumn{2}{|c|}{ Emergence (days) } & \multirow{3}{*}{$\begin{array}{l}\text { Low temperature } \\
\text { exposure (days) }\end{array}$} & \multicolumn{2}{|c|}{ Emergence (days) } \\
\hline & \multicolumn{2}{|c|}{ Rhizome segment $^{y}$} & & \multicolumn{2}{|c|}{ Rhizome segment } \\
\hline & $\overline{\mathrm{Nt}+\mathrm{N} 1}$ & $\mathrm{Nx}$ & & $\overline{\mathrm{Nt}+\mathrm{N} 1}$ & $\mathrm{Nx}$ \\
\hline 30 & $--^{-{ }^{x}}$ & --- & 90 & $11 \mathrm{cA}$ & $11 \mathrm{cA}$ \\
\hline 45 & $27 \mathrm{a} \mathrm{B}^{\mathrm{w}}$ & 37 a A & 90 & $13 \mathrm{c} \mathrm{A}$ & $16 \mathrm{ab} A$ \\
\hline 60 & $19 \mathrm{~b} \mathrm{~B}$ & $24 \mathrm{~b} \mathrm{~A}$ & 90 & $21 \mathrm{a} \mathrm{A}$ & $13 a-c B$ \\
\hline 75 & $13 \mathrm{c} \mathrm{B}$ & $18 \mathrm{c} \mathrm{A}$ & 90 & $19 \mathrm{ab} A$ & 17 a A \\
\hline 90 & $10 \mathrm{c} \mathrm{B}$ & $27 \mathrm{~b} \mathrm{~A}$ & 90 & 21 a A & 17 a A \\
\hline \multicolumn{6}{|c|}{ Significance } \\
\hline re $(E)$ & \multicolumn{3}{|c|}{$<0.0001$} & \multicolumn{2}{|c|}{0.0001} \\
\hline Rhizome (R) & \multicolumn{2}{|c|}{$<0.0001$} & & \multicolumn{2}{|c|}{0.0691} \\
\hline$E \times R$ & \multicolumn{2}{|c|}{0.0001} & & \multicolumn{2}{|c|}{0.0055} \\
\hline \multicolumn{6}{|c|}{$\begin{array}{l}{ }^{\mathrm{r}} \text { Growth cycle I: Low temperature exposure }\left(\approx 4{ }^{\circ} \mathrm{C}\right) \text { for } 30,45,60,75 \text {, or } 90 \mathrm{~d} \text { prior to growth in pots } \\
\text { in a greenhouse. Growth cycle II: Following senescence, pots were given low temperature exposure } \\
\left(\approx 4^{\circ} \mathrm{C}\right) \text { for } 90 \text { days and again placed in a greenhouse. Values are means of } 15 \text { replications. } \\
\text { nodwo-node rhizome segment with one terminal and an adjacent one-year-old node }(\mathrm{Nt}+\mathrm{N} 1) \text {. One- } \\
\text { node rhizome segment, not a terminal node, of unknown age or rhizome position }(\mathrm{Nx}) \text {. } \\
{ }^{\mathrm{y}} \text { Shoots did not emerge, or did not emerge in sufficient numbers, for analysis when given } 30 \mathrm{~d} \text { of } \\
\text { exposure during growth cycle I. } \\
\text { w Values in columns or rows followed by the same lowercase or uppercase letters, respectively, } \\
\text { were not significantly different at } P \leq 0.05 \text {. }\end{array}$} \\
\hline
\end{tabular}

decreased $12 \%$. Shoot longevity for $90 \mathrm{~d}$ of exposure increased slightly compared to the 75-d exposure, but this was not different than that of all other durations. Shoots arising from Nx rhizome segments also exhibited fewerd of shoot longevity as low temperature exposure increased from 45 to $75 \mathrm{~d}$. Shoot longevity for the 90-d exposure was not different than that of the 75-d exposure. Shoot longevity of mayapple was reported to be influenced by plant vigor, with larger and more vigorous rhizome systems producing longer-lived shoots than smaller and less vigorous rhizome systems (Watson and Lu, 1999). Duration of low temperature exposure may influence rhizome vigor, which in turn may affect shoot longevity. Shoot longevity also may have been affected by greenhouse conditions, with shoots arising from rhizome segments receiving $90 \mathrm{~d}$ of low temperature exposure experiencing slightly warmer greenhouse temperatures and slightly longer $d$ than shoots arising from rhizomes segments receiving $75 \mathrm{~d}$ or fewer of low temperature exposure.

Duration of low temperature exposure did not affect shoot leaf area (Table 4). However, shoots arising from $\mathrm{Nt}+\mathrm{N} 1$ segments produced three times more leaf area than shoots arising from $\mathrm{Nx}$, indicating that $\mathrm{Nt}+\mathrm{N} 1$ produced segments that produced shoots, only one shoot per propagule emerged (Table 5).

Duration of low temperature exposure and type of rhizome segment affected shoot height (Table 6). Increasing duration of low temperature exposure from 45 to $90 \mathrm{~d}$ increased plant height by $\approx 37 \%$. Segment type had a slightly greater effect on plant height than duration of low temperature exposure, with $\mathrm{Nt}+\mathrm{N} 1$ shoots being $44 \%$ taller than $\mathrm{Nx}$ shoots. As mentioned above, however, greenhouse conditions also may have affected shoot height. larger leaves than that of Nx. Of the rhizome

Table 3. Longevity of shoots arising from mayapple rhizome segments harvested from the wild and exposed to low temperatures.

\begin{tabular}{|c|c|c|c|c|c|}
\hline \multicolumn{3}{|c|}{ Growth cycle $\mathrm{I}^{2}$} & \multicolumn{3}{|c|}{ Growth cycle II } \\
\hline \multirow{3}{*}{$\begin{array}{l}\text { Low temperature } \\
\text { exposure (days) }\end{array}$} & \multicolumn{2}{|c|}{ Shoot longevity (days) } & \multirow{3}{*}{$\begin{array}{l}\text { Low temperature } \\
\text { exposure (days) }\end{array}$} & \multicolumn{2}{|c|}{ Shoot longevity (days) } \\
\hline & \multicolumn{2}{|c|}{ Rhizome segment } & & \multicolumn{2}{|c|}{ Rhizome segment } \\
\hline & $\mathrm{Nt}+\mathrm{N} 1$ & $\mathrm{Nx}$ & & $\mathrm{Nt}+\mathrm{N} 1$ & $\mathrm{Nx}$ \\
\hline 30 & $--^{x}$ & --- & 90 & $85 \mathrm{bc} \mathrm{A}$ & $92 \mathrm{ab} A$ \\
\hline 45 & $122 \mathrm{a} \mathrm{A}^{\mathrm{w}}$ & 127 a A & 90 & $77 \mathrm{c} \mathrm{A}$ & $84 \mathrm{ab} A$ \\
\hline 60 & $117 \mathrm{ab} \mathrm{A}$ & $107 \mathrm{~b} \mathrm{~B}$ & 90 & $99 \mathrm{ab} A$ & $81 \mathrm{~b} \mathrm{~B}$ \\
\hline 75 & $107 \mathrm{~b} A$ & 92 c B & 90 & $99 \mathrm{ab} \mathrm{A}$ & 96 a A \\
\hline 90 & $113 a b$ A & $84 \mathrm{c} \mathrm{B}$ & 90 & 105 a A & $78 \mathrm{~b} \mathrm{~B}$ \\
\hline \multicolumn{6}{|c|}{ Significance } \\
\hline Exposure (E) & \multicolumn{2}{|c|}{$<0.0001$} & & \multicolumn{2}{|c|}{0.0181} \\
\hline Rhizome (R) & \multicolumn{2}{|c|}{0.0042} & & \multicolumn{2}{|c|}{0.0374} \\
\hline$E \times R$ & \multicolumn{2}{|c|}{0.0172} & & \multicolumn{2}{|c|}{0.0010} \\
\hline
\end{tabular}

${ }^{2}$ Growth cycle I: Low temperature exposure $\left(\approx 4^{\circ} \mathrm{C}\right)$ for $30,45,60,75$, or $90 \mathrm{~d}$ prior to growth in pots in a greenhouse. Growth cycle II: Following senescence, pots were given low temperature exposure $\left(\approx 4{ }^{\circ} \mathrm{C}\right)$ for $90 \mathrm{~d}$ and again placed in a greenhouse. Values are means of 15 replications.

'Two-node rhizome segment with one terminal and an adjacent 1-year-old node (Nt+N1). One-node rhizome segment, not a terminal node, of unknown age or rhizome position (Nx).

${ }^{x}$ Shoots did not emerge, or did not emerge in sufficient numbers, for analysis when given $30 \mathrm{~d}$ of exposure during growth cycle I.

walues in columns or rows followed by the same lowercase or uppercase letters, respectively, were not significantly different at $P \leq 0.05$. 
Table 4. Total leaf area of shoots arising from mayapple rhizome segments harvested from the wild and exposed to low temperatures.

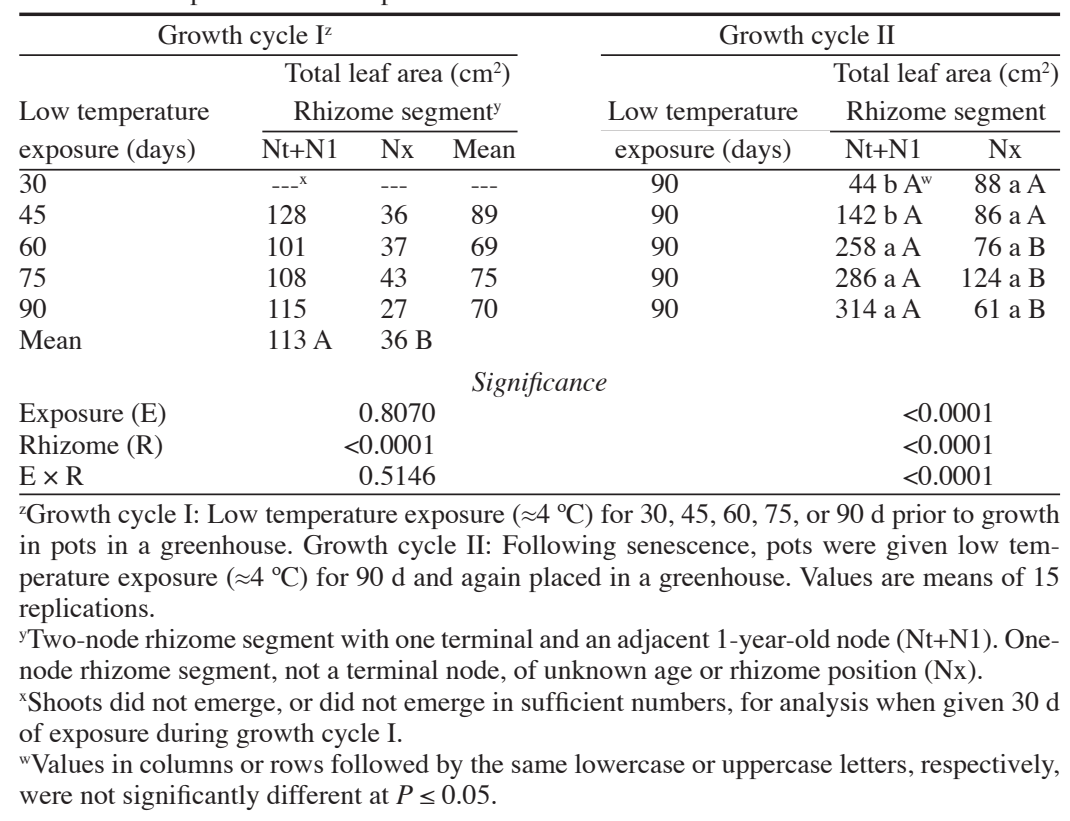

Growth cycle II. Emergence of shoots from $\mathrm{Nt}+\mathrm{N} 1$ and $\mathrm{Nx}$ rhizome segments following a second low temperature exposure, this time of $90 \mathrm{~d}$, ranged from $60 \%$ to $100 \%$ (Table 1). Segments that did not produce shoots, or produced few shoots, during growth cycle I when given $30 \mathrm{~d}$ of initial low temperature exposure emerged at much greater percentages during growth cycle II. Apparently, mayapple rhizomes can endure long periods of dormancy and still produce shoots when exposed to durations of low temperature sufficient to break that dormancy.

There was a significant interaction between initial duration of low temperature exposure and type of rhizome segment for average $d$ to shoot emergence (Table 2). As the initial duration of low temperature exposure given during growth cycle I increased from 30 to

$90 \mathrm{~d}$, shoots arising from $\mathrm{Nt}+\mathrm{N} 1$ rhizome segments during growth cycle II required about twice as many days to emerge. Shoots arising from $\mathrm{Nx}$ rhizome segments required $\approx 50 \%$ more days to emerge as duration of low temperature exposure increased from 30 to $90 \mathrm{~d}$. Type of rhizome segment did not affect days to shoot emergence, except at $60 \mathrm{~d}$ of initial low temperature exposure, for which $\mathrm{Nt}+\mathrm{N} 1$ required more days to emerge than Nx. The overall trend of these data are opposite of that observed during growth cycle I, where increasing durations of low temperature exposure generally decreased days to shoot emergence. Greenhouse conditions during growth cycle II were generally opposite of those during growth cycle I, with slightly decreasing temperature and daylength compared to growth cycle II.

Table 5. Number of shoots arising from mayapple rhizome segments harvested from the wild and exposed to low temperatures.

\begin{tabular}{|c|c|c|c|c|c|c|}
\hline \multicolumn{3}{|c|}{ Growth cycle $\mathrm{I}^{\mathrm{z}}$} & \multicolumn{4}{|c|}{ Growth cycle II } \\
\hline \multirow{3}{*}{$\begin{array}{l}\text { Low temperature } \\
\text { exposure (days) }\end{array}$} & \multicolumn{2}{|c|}{ Shoots/pot } & \multirow{3}{*}{$\begin{array}{l}\text { Low temperature } \\
\text { exposure (days) }\end{array}$} & \multicolumn{3}{|c|}{ Shoots/pot } \\
\hline & Rhizom & gment $^{y}$ & & \multicolumn{3}{|c|}{ Rhizome segment } \\
\hline & $\mathrm{Nt}+\mathrm{N} 1$ & $\mathrm{Nx}$ & & $\mathrm{Nt}+\mathrm{N} 1$ & $\mathrm{Nx}$ & Mean \\
\hline 30 & $--^{x}$ & --- & 90 & 1.8 & 1.6 & 1.7 \\
\hline 45 & 1.0 & 1.0 & 90 & 1.8 & 1.6 & 1.7 \\
\hline 60 & 1.0 & 1.0 & 90 & 2.5 & 1.4 & 2.0 \\
\hline 75 & 1.0 & 1.0 & 90 & 2.2 & 1.4 & 1.8 \\
\hline 90 & 1.0 & 1.0 & 90 & 2.4 & 1.3 & 1.9 \\
\hline Mean & & & & $2.2 \mathrm{~A}^{\prime \prime}$ & $1.5 \mathrm{~B}$ & \\
\hline
\end{tabular}

Significance

$\begin{array}{ll}\text { Exposure (E) } & 0.6843 \\ \text { Rhizome (R) } & 0.0001\end{array}$

$\mathrm{E} \times \mathrm{R} \quad 0.0521$

${ }^{\mathrm{z}}$ Growth cycle I: Low temperature exposure $\left(\approx 4{ }^{\circ} \mathrm{C}\right)$ for $30,45,60,75$, or $90 \mathrm{~d}$ prior to growth in pots in a greenhouse. Growth cycle II: Following senescence, pots were given low temperature exposure $\left(\approx 4{ }^{\circ} \mathrm{C}\right)$ for $90 \mathrm{~d}$ and again placed in a greenhouse. Values are means of 15 replications. Data reported for growth cycle I did not exhibit any variation. Therefore, these data were not statistically analyzed.

yTwo-node rhizome segment with one terminal and an adjacent 1-year-old node (Nt+N1). Onenode rhizome segment, not a terminal node, of unknown age or rhizome position $(\mathrm{Nx})$.

${ }^{x}$ Shoots did not emerge, or did not emerge in sufficient numbers, for analysis when given $30 \mathrm{~d}$ of exposure during growth cycle I.

${ }^{\text {w } M e a n s ~ s i g n i f i c a n t l y ~ d i f f e r e n t ~ a t ~} P \leq 0.05$.
There was a significant interaction between duration of low temperature exposure and type of rhizome segment for days of shoot longevity (Table 3). As the initial duration of low temperature exposure during growth cycle I increased from 30 to $90 \mathrm{~d}$, d of shoot longevity of shoots arising from $\mathrm{Nt}+\mathrm{N} 1$ rhizome segments during growth cycle II increased about $25 \%$. In contrast, shoot longevity of shoots arising from $\mathrm{Nx}$ segments exhibited no clear trend, fluctuating as much as $20 \%$ as a result of initial duration of exposure. Type of rhizome segment affected only shoots exposed to 60 and 90 d of low temperature, with days of shoot longevity for $\mathrm{Nx}$ segments being significantly less than that of $\mathrm{Nt}+\mathrm{N} 1$ segments.

There was a significant interaction between duration of low temperature exposure and type of rhizome segment for total leaf area (Table 4). As the initial duration of low temperature exposure during growth cycle I increased from 30 to $90 \mathrm{~d}$, shoots arising from $\mathrm{Nt}+\mathrm{N} 1$ rhizome segments during growth cycle II increased leaf area by about seven-fold. In contrast, shoots arising from $\mathrm{Nx}$ segments during growth cycle II appeared unaffected by the initial low temperature exposures.

Rhizome segment affected the number of shoots produced by each propagule (Table 5). $\mathrm{Nt}+\mathrm{N} 1$ and $\mathrm{Nx}$ rhizome segments produced more shoots during growth cycle II compared to growth cycle I. In addition, during growth cycle II $\mathrm{Nt}+\mathrm{N} 1$ segments produced $\approx 50 \%$ more shoots than Nx segments. These data show that when given repeated low temperature exposures, rhizome segments with two nodes $(\mathrm{Nt}+\mathrm{N} 1)$ were able to produce more shoots per propagule than those with only one node $(\mathrm{Nx})$.

There was a significant interaction between duration of low temperature exposure and type of rhizome segment for plant height (Table 6). As the initial duration of low temperature exposure during growth cycle I increased from 30 to $90 \mathrm{~d}$, plant height of shoots arising from $\mathrm{Nt}+\mathrm{N} 1$ rhizome segments during growth cycle II more than doubled. In contrast, and as with leaf area, shoots arising from Nx segments during growth cycle II appeared unaffected by the initial low temperature exposures.

\section{Conclusions}

Overall, rhizome segments exposed initially to 60,75 , or $90 \mathrm{~d}$ of low temperature emerged in greater numbers and grew better than those exposed to 30 or $45 \mathrm{~d}$. The threshold duration of low temperature to overcome dormancy of mayapple rhizomes appears to be $60 \mathrm{~d}$, with segments receiving < $60 \mathrm{~d}$ emerging in fewer numbers and producing smaller plants than segments receiving $60 \mathrm{~d}$ or more. With $60 \mathrm{~d}$ being the threshold, the optimum duration of exposure may be $75 \mathrm{~d}$. These results are similar to those reported for overcoming the dormancy of myoga (Follett, 1991; Gracie et al., 2000) and lily-of-the-valley (Wareing and Phillips, 1981) rhizome segments, where increasing durations of low temperature exposure improved shoot emergence and growth. Compared to lily-of-the-valley, however, may- 
Table 6. Plant height of shoots arising from mayapple rhizome segments harvested from the wild and exposed to low temperatures.

\begin{tabular}{|c|c|c|c|c|c|c|}
\hline \multicolumn{4}{|c|}{ 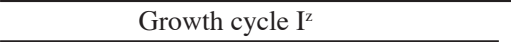 } & \multicolumn{3}{|c|}{ Growth cycle II } \\
\hline & \multicolumn{3}{|c|}{ Plant height $(\mathrm{cm})$} & \multirow{3}{*}{$\begin{array}{l}\text { Low temperature } \\
\text { exposure (days) }\end{array}$} & \multicolumn{2}{|c|}{ Plant height $(\mathrm{cm})$} \\
\hline \multirow{2}{*}{$\begin{array}{l}\text { Low temperature } \\
\text { exposure (days) }\end{array}$} & \multicolumn{3}{|c|}{ Rhizome segment $^{y}$} & & \multicolumn{2}{|c|}{ Rhizome segment } \\
\hline & $\mathrm{Nt}+\mathrm{N} 1$ & $\mathrm{NX}$ & Mean & & $\overline{\mathrm{Nt}+\mathrm{N} 1}$ & $\mathrm{Nx}$ \\
\hline 30 & $--^{x}$ & --- & --- & 90 & $6 \mathrm{c} \mathrm{B}^{\mathrm{w}}$ & 9 a A \\
\hline 45 & 24 & 14 & $19 \mathrm{~b}$ & 90 & $9 \mathrm{~b} \mathrm{~A}$ & 9 a A \\
\hline 60 & 26 & 19 & $22 \mathrm{ab}$ & 90 & 13 a A & 10 a B \\
\hline 75 & 24 & 19 & $22 \mathrm{ab}$ & 90 & 14 a A & 11 a B \\
\hline 90 & 29 & 22 & $26 \mathrm{a}$ & 90 & 15 a A & 9 a B \\
\hline Mean & $26 \mathrm{~A}$ & $18 \mathrm{~B}$ & & & & \\
\hline \multicolumn{7}{|c|}{ Significance } \\
\hline Exposure (E) & \multicolumn{3}{|c|}{0.0135} & & \multicolumn{2}{|c|}{$<0.0001$} \\
\hline Rhizome (R) & \multicolumn{2}{|c|}{0.0004} & & & \multicolumn{2}{|c|}{0.0012} \\
\hline$E \times R$ & \multicolumn{2}{|c|}{0.7928} & & & \multicolumn{2}{|c|}{$<0.0001$} \\
\hline
\end{tabular}

${ }^{\mathrm{z}}$ Growth cycle I: Low temperature exposure $\left(\approx 4^{\circ} \mathrm{C}\right)$ for $30,45,60,75$, or $90 \mathrm{~d}$ prior to growth in pots in a greenhouse. Growth cycle II: Following senescence, pots were given low temperature exposure $\left(\approx 4{ }^{\circ} \mathrm{C}\right)$ for $90 \mathrm{~d}$ and again placed in a greenhouse. Values are means of 15 replications.

'Two-node rhizome segment with one terminal and an adjacent 1-year-old node (Nt+N1). Onenode rhizome segment, not a terminal node, of unknown age or rhizome position (Nx).

${ }^{x}$ Shoots did not emerge, or did not emerge in sufficient numbers, for analysis when given $30 \mathrm{~d}$ of exposure during growth cycle I.

"Values in columns or rows followed by the same lowercase or uppercase letters, respectively, were not significantly different at $P \leq 0.05$.

apple requires about three times the duration of low temperature exposure at $\approx 4{ }^{\circ} \mathrm{C}$ to break dormancy. Some effects of low temperature exposure of mayapple during growth cycle I persisted to growth cycle II.

Rhizome segments $\mathrm{Nt}+\mathrm{N} 1$ performed better during each growth cycle than $\mathrm{Nx}$ for most aspects of growth and development. The $\mathrm{Nt}+\mathrm{N} 1$ segments generally exhibited equal or greater percent shoot emergence, shoot longevity, leaf area, plant height, and shoots per propagule than $\mathrm{Nx}$. The $\mathrm{Nt}+\mathrm{N} 1$ segments also required fewer $\mathrm{d}$ to emergence than $\mathrm{Nx}$ during growth cycle I.

\section{Literature Cited}

Bedir, E., I. Khan, and R.M. Moraes. 2002. Bioprospecting for podophyllotoxin. p. 545-549. In: J. Janick and A. Whipkey (eds.). Trends in new crops and new uses. Proc. Fifth Natl. Symp., New crops and new uses: Strength in diversity.
ASHS Press, Alexandria, Va.

Beutner, K.R. 1996. Podophyllotoxin in the treatment of genital warts, p. 227-232. In: P. Elsner and A. Eichmann (eds.). Sexually transmitted diseases: Advances in diagnosis and treatment. Curr. Probl. Dermatol. Karger, Basel (Switzerland). Vol. 24.

de Kroon, H., D.F. Whigham, and M.A. Watson. 1991. Developmental ecology of mayapple: Effects of rhizome severing, fertilization and timing of shoot senescence. Functional Ecol. 5:360-368.

Foerste, A.F. 1884. The Mayapple. Bul. Torrey Bot. Club: p. 62-64.

Follett, J.M. 1991. Propagation notes for new and novel crops introduced into New Zealand. Comb. Proc. Intl. Plant Prop. Soc. 41:104-109.

Foster, S. 1993. Medicinal plant conservation and genetic resources: Examples from the temperate Northern hemisphere. Acta Hort. 330:67-73.

Fulton, T.A., A.J. Hall, and J.L. Catley. 2001. Chilling requirements of Paeonia cultivars. Scientia
Hort. 89:237-248.

Gracie, A.J., P.H. Brown, S.W. Burgess, and R.J. Clark. 2000. Rhizome dormancy and shoot growth in myoga (Zingiber mioga Roscoe). Scientia Hort. 84:27-37.

Holm, T. 1899. Podophyllum peltatum, a morphological study. Bot. Gaz. 27:419-433.

Krochmal,A., L. Wilkins, D. van Lear, and M. Chien. 1974. Mayapple (Podophyllum peltatum L.). USDA Forest Serv. Res. Paper NE-296.

Laverty, T.M. and R.C. Plowright. 1988. Fruit and seed set in mayapple (Podophyllum peltatum): Influence of intraspecific factors and local enhancement near Pedicularis Canadensis. Can. J. Bot. 66:173-178.

Lehmann, E.L. 1975. Nonparametrics-statistical methods based on ranks. Holden-Day, Oakland, Calif.

Lerndal, T. and B. Svensson. 2000. A clinical study of $\mathrm{CPH} 82$ vs. methotrexate in early rheumatoid arthritis. Rheumatology 39:316-320.

Maqbool, M., K.E. Cushman, and R.M. Moraes. 2002. Propagule type and planting time for field-established mayapple, p. 533-536. In: J. Janick and A. Whipkey (eds.). Trends in new crops and new uses. Proc. Fifth Natl. Symp. New crops and new uses: Strength in diversity. ASHS Press, Alexandria, Va.

Nautiyal, M.C. 1996. Cultivation of medicinal plants and biosphere reserve management in alpine zone. p. 570-582. In: P.S. Ramakrishnan, A.N.Purohit, K.G. Sexena, K.S. Rao, and R.K. Maikhuri. (eds.). Conservation and management of biological resources in Himalayas. Oxford and IBH Publ. Co. New Delhi, India.

Rai,L.K.,P.Prasad, and E. Sharma. 2000. Conservation threats to some important medicinal plants of the Sikkim Himalaya. Biolog. Conservation 93:27-33.

Rust, R.W. and R.R. Roth. 1981. Seed production and seedling establishment in the mayapple, Podophyllum peltatum L. Amer. Midland Naturalist 105:51-60.

SAS Institute Inc. 2000. SAS OnlineDoc. Version 8. SAS Inst., Cary, N.C

Wareing, P.F. and I.D.J. Phillips. 1981. Growth and differentiation in plants. $3^{\text {rd }}$ ed. Pergamon Press, New York.

Watson, M.A. and Y. Lu. 1999. Timing of shoot senescence and demographic expression in the clonal perennial Podophyllum peltatum (Berberidaceae). Oikos 86:67-68. 